\title{
The North Star of Hype: How Detroit Charts a Course in a Neoliberal Framework
}

\author{
Crystal Montoya*
}

\begin{abstract}
The city of Detroit is associated with the creation of and rise of industrialism in North America. Industrialism, specifically Fordism, within the municipality of Detroit maintained financial strength for decades until the mid-1980s when a new global capitalist era emerged in the Global North. Currently, the city of Detroit is in the process of rebuilding. In the academic literature on development, there is an apparent gap that explores how current ideologies shape development in social spaces. In this review, the ideological influences of sustainable development and neoliberalism are explored through analysis of the social, historical, political, and economic lenses that contribute to and shape development within the city of Detroit. Moreover, the ideological influences are analyzed to understand how explicit discourse for sustainable development either forms or breaks implicit systems of social control. The paper concludes by acknowledging that progressive notions of equality and growth are difficult to actualize due to the inequitable allocation of capital under our system of global capitalism. The paper closes with an exploration of the implicit and symbolic biases that appears inherent in development ideologies to contribute to a genuine and possible path to an equitable and sustainable future for places such as Detroit.
\end{abstract}

Keywords: development, labour, race, sustainable, urban, neoliberalism

\section{Introduction}

The developmental history of Detroit holds a dual perspective of industrial economic decline and sustainable revitalization. On the one hand, the City of Detroit is a tale of prosperity associated with rapid industrialization, as the rise of automotive manufacturing and Fordism created a

*College of Arts and Science, University of Saskatchewan, Saskatoon, SK, Canada Correspondence: crm679@usask.ca

University of Saskatchewan Undergraduate Research Journal Volume 7, Issue 2, 2021

(C) 2021 Crystal Montoya. This open access article is distributed under

a Creative Commons Attribution Non-commercial 4.0 license.

(https://creativecommons.org/licenses/by-nc/4.0/) 
burgeoning middle class and substantial economic strength. However, these gains were short-lived under new, neoliberal globalized manufacturing processes that began in the 1970 s in response to the emerging political economy and labour organizations. These processes, which outsourced jobs overseas in response to neoliberal demands for capital, effectively created a declining urban core with high unemployment, increasing residential and commercial vacancies, and intensifying income inequality. Detroit is again garnering attention, but as an example to be studied for notions on sustainable development as the city begins to rebuild the urban core to draw back the people to the city (Kinney, 2016).

Previous literature on Detroit has explored the industrial decline of the city, but the relationship between neoliberal ideology and sustainable development, particularly as it extends into equity concerns, is underexplored in academic literature. Therefore, this paper seeks to connect the ideological history of neoliberalism as it informs development and also informs contemporary sustainable development in Detroit by establishing how sustainable development improves equity for Black lives in Detroit or reinforces inequitable systems. Sustainable development in Detroit follows urban and environmental renewal trends, and this paper also examines who is benefitting from the sustainable development initiatives. As the city uses urban poverty and the associated street art, culture, and infrastructure as a revitalization method, the "sustainable" development practices risk reproducing the displacement and marginalization of Black communities in Detroit that occurred during different periods of economic shifts.

The Rise and Fall of the Industrial Labour Workforce in Detroit: Much of the middle class's emergence in America is rooted in the automotive manufacturing expansion at the beginning of the twentieth century, often referred to as "Fordism" (Sugrue, 1996). The rise of the Big Three auto empires, Ford, Chrysler, and GM, from the 1900 s to $1950 \mathrm{~s}$ birthed an era that advanced wage fairness in the western world (Montgomery, 2015). During this time, Detroit became the epicentre for American automotive manufacturing (Sugrue, 1996), and paralleling the growth of the automotive industry was the demand for skilled physical labourers. The demand for skilled labour expanded hiring practices to include Black workers from the southern US.

Because of economic expansion in the Detroit automotive manufacturing industry, Black labourers in the city experienced social and economic mobility. The postWW1 surge of Black workers into Detroit created housing scarcity. The factories offered work but not access to living conditions higher earnings could provide (NAACP). Black individuals received wages similar to their White counterparts and gained the capacity to purchase on par, meaning that Black people could afford material goods.
Affordability of goods meant that racialized people could integrate where they were once economically separated due to wage inequality (Thompson, 1999). And afford material items like cars and houses and occupy neighbourhoods that had historically been affordable to only White people (Darden \& Kamel, 2000).

Though economic integration increased, homeownership remained predominately available to White populations, while most Black residents rented (Darden \& Kamel, 2000). Laws and policies for homeownership and mortgages discriminated against Black ownership (NAACP, 2016). By the 1920 s and into the 19305 , most Black industrial workers were living in ghettoized conditions with middleclass wages (Rothstein, 2017).

To address housing disparity, the Detroit Housing Commission (DHC) formed in 1933, and under Roosevelt's New Deal, federal funding was available for AfricanAmerican homeownership (Rothstein, 2017). In 1934, the Federal Housing Act was ratified to address housing scarcity and living conditions for racialized populations in the United States (Rothein, 2017; Detroit Historical Society, n.d.). However, the DHC used policy interventions such as the Underwriting Manual, from the Federal Housing Administration, and the Home-Owners Loan Corporation to physically segregate urban neighbourhoods based on racial profiling (Rothstein, 2017; Clement \& Kanai, 2015). The segregate zoning created separate neighborhoods and locations for Black people living in Detroit, dividing the city by racialized spaces.

The patterns of change take on spatial concreteness in that the racial relations are visible in the dividing lines of streets and neighborhoods. As noted by Lipsitz (2007), "the lived experience of race has a spatial dimension, and the lived experience of space has a racial dimension" (p. 12). Lower-income and middle-income neighbourhoods, like Paradise Valley, in Detroit were commonly comprised of racialized populations (Martelle, 2014). These neighbourhoods that are both lower-income and racialized are vulnerable, as there is an intersection of disempowerment economically, socially, and politically to change the dynamic of poverty and racialization (Montgomery, 2015).

The infamous ' 8 Mile' road was constructed in 1941 to maintain separate racialized neighbourhoods (Rothstein, 2017). The 8 Mile is a road that intersects the city and divides White and Black communities, like the once segregated community of Paradise Valley (Kinney, 2016). The divisional lines of roads and neighbourhoods contoured the hypervisibility of Black segregation with the invisibility of white privilege, implicit in policies and legislation of the time (Surgue, 1996). The asymmetries of the policies became visible in a short amount of time as racially segregated communities lack critical infrastructure (Detroit Historical Society, n.d). The exacerbation of living and working 
conditions led to a riot in 1943 (Detroit Historical Society, n.d.). The longstanding conflict and unequal civil rights tensions endured and evolved over the next decade.

The City of Detroit maintained its economic position until the late 1960s, when Detroit's White population began to exit the urban core in fear of rising racial tensions (Thompson, 1999). White populations began to exit the urban core as Black populations increased and civil rights movements for equality gained momentum and civil power (Rothstein, 2017). Equality movements in Detroit grew out of frustration with systemic police discrimination, housing inaccessibility, and employment inequalities (Kinney, 2016; Montgomery, 2015). In 1967 the Detroit Riot became a national focal point in the Civil Rights Movement as media covered the experiences of Black people in the city (Solomon, 2014). Sustained tensions after the riot intensified racial divisions of housing, education, industrial development, and labour.

\section{Globalization and the Fall of Detroit}

During the '70s and the '8os, Detroit's economy buckled due to continued labour disputes and workers' demands for equality. In response to pressures for labour equity, the Big Three Automakers implemented offshoring, by moving manufacturing operations overseas to obtain raw materials and human resources for a reduced cost (Sugrue, 2014). The development practices in Detroit, a narrow sector focused on automotive manufacturing, served to reinforce the status quo of the industry strength in the region. The City of Detroit lost manufacturing jobs and local employment en masse, as globalization throughout the 1970 s mechanized production and moved manufacturing overseas. Loss of domestic work particularly impacted racialized persons. As the manufacturing labourers in Detroit were primarily Black, this created both a problem for 'unskilled' labourers and further deepened racial divisions in the polarized city (Brockmeyer, 2000).

The influence of neoliberalism impacted Detroit's Black populations and global workers were left marginalized. The City of Detroit is a demonstrative lead in the development of neoliberal capitalist ideology for local and international developments. Moreover, the pathway created a trail of degradation of opportunity for Black and marginalized persons. The influence of globalization is observed domestically in reducing domestic jobs, particularly for racialized persons. Globalization is also a driving force of the relocation of manufacturing to international shores, and supply-chain restructuring was observed from the 1970 s onward (Johnson, 2002). The influence of globalization is observed domestically in reducing domestic jobs, particularly for racialized persons. Furthermore, high-cost unionized wages no longer required toleration, as manufacturers could increase profits and decrease wages by relocating operations (Sugrue, 2014; Lawless, 2002). A central tenancy for global capitalism is to pursue the lowest bidder for labour capital (Ampuja, 2012). Moreover, 'live' labour was becoming obsolete with 'dead' labour, as "further technological innovation introduced more machinery into the assembly lines" (Thomas, 1999). Thus, technological advances allow the industry to either relocate or replace the workforce in the most efficient manner. The reduction of meaningful employment and accessibility of options forced a state of regional despair for industrial labourers, and the impact rippled through the region, dependent on Detroit (Linkon, 2013; Trachte \& Ross, 2003; Lawless, 2002).

The social and economic landscape in Detroit was problematic due to the deindustrialization of the auto factories in Detroit, and the subsequent loss of labour (Kurashige, 2017). The auto workers that remained accepted wages negotiated at lower rates, in order to have some financial certainty (Reuther, 2012). The wages were not enough to maintain the daily expenses (Reuther, 2012). The long history of redlining and housing in Detroit now was intersecting with the loss of wages that had created a Black middle class (Rothstein, 2017; Kurashige, 2017; LeDuff, 2013). The financial destabilization of job loss, deskilling, and wage reductions for people still employed opened up the disadvantaged workers to sub-prime loans.

In Detroit, between 2004 to 2006 , over $75 \%$ of mortgages loans were subprime (Gottesdiener, 2013). After the 2008 financial recession banks began to foreclose. By 2012 , about $30 \%$ of all residences, or over 100,000 homes in Detroit were foreclosed (Kurashige, 2017; Gottesdiener, 2013; Dynamics of Decay, Abandonment, and Bankruptcy, 2012) The large vacant lots and abandoned homes attracted tourism to Detroit to view the ruins. By 2013, the city of Detroit filed for municipal bankruptcy (Davey \& Walsh, 2013). Vacancies left the city funds depleted, but suburban communities to continue thriving and expanding (Kinney, 2018; Kinney, 2016; LeDuff, 2013). The stakes of foreclosure were high, as crises in pension, wages, services, and other vital supports occurred in close succession with one another (Beyond Bankruptcy, 2014). To mitigate the foreclosures and bankruptcy, initiatives to rebuild Detroit emerged.

\section{Sustainable Neoliberal Development}

From 2013 onwards, Detroit is taking on new and previously unused paths in local development to address urban decline and meet the objectives of sustainability (Redmond, 2013). However, these contemporary developments for Detroit are problematic for neoliberal agendas (Clement \& Kanai, 2015). Current neoliberal constructs seek to gain in profit and often that includes minimizing costs such as wages (Harvey, 2005). 
Municipal and media campaigns are touting a rebranded 'New Detroit' as a progressive phoenix rising from the fires of ruin (Kinney, 2016). The propaganda frames the ascent from the economic decline, but negates to discuss if contributing factors such as inequitable policies and systemic discrimination will remain embedded policies. Propaganda also problematically skip over the longstemming political contributions to the decline (Rothstein, 2017).

Such campaigns and economic propaganda have resulted in significant investment into Detroit proper (Marr, 2016). Political campaigns that focus on the return of industrialization and manufacturing jobs ignore the unequal provision of benefits between citizens, and which citizens will receive the most benefit (Doucet, 2017; Marr, 2016). Again, political campaigns promise that wages will return high living standards but neglect to discuss the generationally transformed economic realities of the region, as skill sets are lost or workers are reskilled in new occupations (Doucet, 2017; Erving, 2015). Further, political solutions promoted do not restore opportunities to those who lost work, but to an emerging suburban middle class (Kinney, 2017). The policies for the social and economic development serve the middle-class by focus on raising and using capital, and the emergence of entrepreneurial development.

Entrepreneurialism has long shaped the contours of policy and has become deeply embedded into Detroit's new municipal growth policies (Rothstein, 2017; Marr, 2016). There is low citizen support of the municipal growth policies. The lack of public-citizen support stems from the different perspectives introduced into the policies that are advanced (Marr, 2016). In place of direct investments into critical public infrastructure, city council and development organizations are investing in private developments (Marr, 2016). For example, a new Little Caesar's arena has been built in Detroit and is home to the Detroit Pistons and the Detroit Red Wing professional sports team (Kinney, 2016), while public infrastructure, including water sanitation, public transportation, and private low-income neighborhoods are rotting (Marr, 2016). The citizens of Detroit critique the focus of city developers on short-term profit margins and suburban attraction as opposed to redeveloping the city itself for all citizens to benefit (Marr, 2016).

Local billionaire Gilbert, the owner of Quicken Loans and the Cleveland Cavaliers, has initiated a major urban gentrification project. Gilbert has purchased over 90 properties in Detroit's downtown core for an estimated USD 1 Billion (Muller, 2014). Gilbert has supplemented these investments with hundreds of millions of dollars streaming into revitalization projects (Muller, 2014). The Detroit Economic Growth Corporation (DEGC) supports Dan Gilbert's advances and his corporate strategies for urban renewal (Detroit Economic Growth Corporation, 2017). The combination of political backing and centralized financial control of renewal projects leaves little room for the voices of the people.

Constructing a "new Detroit" seems to reinforce the dominance of neoliberal hegemony and its constituent racism in the unevenly resurgent American economy (Clement \& Kanai, 2015, p. 372). The hollowed-out core of Detroit proper is a museum of neglect, restored into a shrine for neoliberal agendas (Kinney, 2016). Spatial segregation persists as divisions are valorizing for middle-class suburbanites restoring the ruins of a once shrinking Black city (Kinney, 2018; Clement \& Kanai, 2015). The spatial divisions are now observable as trending sustainable practices take space in the cityscape (Kinney, 2018). The commodification of artifacts of poverty and hegemonic resistance in graffiti art are selling features to the suburban core as exotic slums reclaimed. Indeed, these reclaimed cultural symbols act as a siren which draws in the wealthy middle class.

Without eradicating the causal ideological influences, Detroit's sustainable developments will add to the "worsening conditions of social injustice, racial inequality, urban poverty, and environmental degradation across the US and beyond" (Linder, 2016, p. 2; Apel, 2015). As such, the downtown core's current gentrification only restores a concentration of power and wealth to elite capitalists instead of empowering the ordinary people (Montgomery, 2014). The movement away from neoliberalism that emerged in the 1970 s is reproduced through populism in a sustainably branded neoliberalism that is profiting in progressive notions (Kinney, 2016; Clement \& Kanai, 2015). Moreover, without a critical examination of the contemporary socio-political neoliberal factors that could reproduce inequity of race and income in policies and development strategies, the city of Detroit will spiral into a repetitious cycle of its past.

Lowe (1996) draws out how cultural cycles locate narratives that "place, displace, and replace individuals " ( $p$. 31) by what they recall and what they do not. In racialized spaces, suppression of overt markers of prejudice is common to avoid criticism of inequality (Wittenberg, 2000). As such, racial separation often flows into implicit discourse. In Detroit, it is implicit in the undergird of cultural production and expressed through privileges to dominant groups (Martelle, 2014). Deeply entrenched colonial locations have crystallized and secreted replications in contemporary forms, where racial dominance still reigns (Lowe, 1996). Spatial colonial practices of pushing populations out began in Detroit with Indigenous populations. Detroit is a Frenchsettlement that "occupies the contemporary and ancestral homelands of three Anishinaabe nations of the Council of Three Fires: the Ojibwe, Ottawa, and Potawatomi" (National Park Service, n.d.). The practice of spatial colonial practice 
shifted as Detroit was once the last stop on the underground railroad, the North Star (Marr, 2016).

Detroit has a long history of colonial practice, in racial subjugation but also as a place of divergence and resistance from systemic discrimination and oppression. These long attachments of structural racism in Detroit, are spatial as well and reside in the historical purpose of buildings, roadways, and neighbourhoods (Kinney, 2018; Kinney, 2016; Safransky, 2013). More specifically, the portrayal of the city of Detroit as "a model green city for the new century, with bike paths, urban farms, and grassroots sustainability nudg[es] aside [the] planned obsolescence" (Binelli, 2012, p. 15-16). Contrastively, the green movement is benefiting as a commercial commodity instead of supporting the people in the community that is allegedly benefitting from an environment with a fresh coat of green paint. The current developments do little to support the 'green' and 'sustainable' themes central to the new city blitz and neglect to bring attention to the conditions for which caused the decline of the city to begin with (Doucet, 2017). Arguments have arisen that 'green' packaging put upon neoliberalism, for 'green' capitalism only supports sameness (Bentley, McCutcheon, Cromley, \& Hanink, 2016).

Endeavors to renew the city and to make Detroit 'green' have been trending in media narratives. The current revitalization includes "greenways that organically link vacant locks across city blocks, increasing the density of tree coverage, and a controlled restoration of wildlife that does not interfere with human activities" (Clement \& Kanai, 2015, p. 375). Critical geographers have also demonstrated that what is now regarded as neoliberal urbanism emerged not only amid economic transformations but also as a "byproduct of global processes of territorial state ..." (Clement \& Kanai, 2015, p. 371). The current developments do little to support the 'green' and 'sustainable' themes central to the new city blitz and neglect to bring attention to the conditions for which caused the decline of the city to begin with (Doucet, 2017). More specifically, the portrayal of the city of Detroit as "a model green city for the new century, with bike paths, urban farms, and grassroots sustainability nudg[es] aside [the] planned obsolescence" (Binelli, 2012, p. 15-16). Arguments have arisen that 'green' packaging put upon neoliberalism, for 'green' capitalism only supports sameness.

Culture wars and racial tensions eroded the population in the 'white flight,' and now culture is used as a siren to draw in White populations back to Detroit's core and displace them (Doucet, 2017). The new cultural narratives supporting the rise and fall symbolism fail equality by accrediting the global capitalist influence with sustainable urban environments (Kinney, 2016). The attributions of White heroism- pitted against Black decline- perpetuates the historic racialized divisions, which do not serve to integrate Detroit culturally nor to build a sustainable future for the city
(Carey, 2013; Pedroni, 2011; Trachte \& Ross, 2003). In Detroit, many racial markers are suppressed to avoid the scrutiny of overt prejudice and discrimination; therefore, racial separation often flows into implicit discourse, and for Detroit, it is tacit to cultural expression (Robinson, 2016; Clement \& Kanai, 2015). Local Detroiters are asking: for whom is the city of Detroit being rebuilt? Is the city's robust platforms for the everyday people to gain power and agency or those already in power. The ambitions to change Detroit are rife with injustices as the intergenerational impacts of inequality are still unaddressed (Clement \& Kanai, 2015, p. 381).

Part of Detroit's rise has been awarded to the reputation that Detroit is now a haven for artists. Large, deconstructed buildings provide a canvas for street artists, also referred to as graffiti artists. The images left on the buildings amplify the environment and the ghettoized street feel of a real and raw urban metropolis (Lough, 2016). Street art has been a beacon for cultural curators that award merit to street art and promote the medium as a direct and unfiltered channel to the realities of life for urban poverty in Detroit (Montgomery, 2015). The visual use of art as murals on city buildings evokes and echoes the city's urban decay left in ruin. The art holds appeal for many observers and draws some graffiti artists of international acclaim. The art on the buildings from the renowned graffiti artists holds a higher value than the buildings themselves. Where once graffiti was a form of protest, now the use of graffiti art is used to popularize a narrative of raw urbanity and the 'streets of Detroit' to a growing middle-class class that has displaced the original inhabitants of the city.

Finding that sustainable development risks reproduction of inequality due to underlying neoliberal ideological structures, sustainable development in Detroit will act as a beacon to other 'shrinking cities' and underdeveloped communities (Barndt, 2009). The developmental narratives of the City of Detroit act as a symbol to expose how conflated ideologies undermine sustainable development, and in turn, reinforce neoliberal dominance (Kinney, 2018; Clement \& Kanai, 2015; Brockmeyer, 2000). Finding that sustainable development risks reproduction of inequality due to underlying neoliberal ideological structures. The developmental history of the City of Detroit is representative of the lived experiences of the global systems commonly regarded as 'American' ideals (Erving, 2015). However, these now globalized notions no longer serve to strengthen the economies within but have instead evolved into a force that is neither concrete nor isolative and, as such, can no longer be identified inherently as 'American' (Doucet, 2017). Therefore, if a city, region, or company is no longer profitable or viable to the global systems at play, its fall is arguably inevitable (Kinney, 2016; Massey, 2005). The iconic power of the City of Detroit holds 
narrative lines of both rise and ruin and is a symbol for other municipalities constrained by neoliberalism.

Future research into how ideologies expand and are reproduced in spatial dimensions, such as cities, is necessary to understand how inequality can be reproduced (Clement \& Kanai, 2015). The reproduction of inequality through ideologies is an area of research explored in this analysis of Detroit's labour market and industrial practices shifted from Fordism to Neoliberalism, and how the shift sustained inequity. How Detroit culturally, socially, and economically changes may be indicative of failures in other sustainability initiatives. Additionally, research is needed on how entrenched historic social inequality is reshaped under progressive ideologies and how the proposed benefits of sustainability are newly measured between diversified groups. Little is known about the actualization of sustainable notions. The introduction of progressive ideologies will impact racialized persons and women, especially in tandem with counteractions towards neoliberalism. With the goal of sustainability is to improve and sustain equality and equity for foreseeable generations.

Though the City of Detroit has promoted lofty goals for urban revival, it cannot attain them when the underlying ideological structure serves to diminish rather than elevate sustainability for the citizens of Detroit. Detroit is not a shining star but rather a beacon of weakness in the global capitalist structure. Detroit reveals that the 'global-north' is not unified but fragmented by stark commercial competition, and not for national or community benefit. The fall of Detroit indicates the fall of the cultural bonds, which gives rise to the commodification of the social. Detroit cannot meet these sustainable development goals due to several multi-faceted factors. First, the pathway Detroit is following for development is in ideological opposition to the rise of the collective against the benefit of the few. The polarized objectives of the people within the politicaleconomic systems used cannot support advances to equality and resource distribution. Second, the racial labour divisions within the social atmosphere of Detroit must be addressed to prevent the repetition of subjugation and segregation under new forms of explicit, implicit, and democratic racism. Third, the cultural and 'green' objectives merely mask an insidious form of capitalism that erodes the value of the endeavor through commoditizing and monetizing the outcomes. Lastly, until Detroit not only rises but awakens to the forces of neoliberalism that control sustainable development will ebb and flow through a continuum of neoliberal constraints that restrain the real potential of the city. 
The North Star of Hype: How Detroit Charts a Course in a Neoliberal Framework (Crystal Montoya)

\section{References}

Ampuja, M. (2012). Globalization theory, medi-centrism and neoliberalism: A critique of recent intellectual trends.Critical Sociology, 38(2), 281-301. https://doi.org/10.1177/08g6920510398018

Apel, D. (2015). Beautiful terrible ruins: Detroit and the anxiety of decline. Rutgers University Press.

Barndt, K. (2009). Memory traces of an abandoned set of futures: Industrial ruins in the postindustrial landscapes of Germany. In J. Hell \& A. Schönle (Eds.), Ruins of Modernity (pp. 270-293). Duke University Press. https://doi.org/10.1215/9780822390749-017

Bentley, G., McCutcheon, P., Cromley, R., \& Hanink, D. (2016). Race, class, unemployment, and housing vacancies in Detroit: An empirical analysis. Urban Geography: Neighbourhood Decline, 37(5), 785-80o. https://doi.org/10.1080/02723638.2015.1112642

Beyond Bankruptcy: Building Power and Resilience. (2014). Othering \& Belonging Institute: UC Berkeley. https://escholarship.org/uc/item/19f10054

Binelli, M (2012). Detroit is the place to be: The afterlife of an American metropolis. Picador.

Brockmeyer, J. L. (2000). A Culture of distrust: The impact of local political culture on participation in the Detroit EZ. Urban Studies, 37(13), 2417-2440. http://www.jstor.org/stable/43196507

Carey, N. (2013). Detroit jobs might return, but workers still lack skills. Reuters. http://www.huffingtonpost.com/2013/08/02/detroi t-jobs-_n_3693303

Clement, D., \& Kanai, M. (2015). The Detroit future city: How pervasive neoliberal urbanism exacerbates racialized spatial injustice. American Behavioral Scientist, 59(3), 369-385. https://doi.org/10.1177/0002764214550306

Darden, J. T., \& Kamel, S. M. (2000). Black residential segregation in the city and suburbs of Detroit: Does socioeconomic status matter? Journal of Urban Affairs, 22(1), 1-13. https://doi.org/10.1111/0735-2166.00036

Davey, M., \& Walsh, M. (2013, July 18). Billions in debt, Detroit tumbles into insolvency. New York Times.
Retrieved from

https://www.nytimes.com/2013/07/19/us/detroitfiles-for-bankruptcy.html?pagewanted=all\&_r=0

Detroit Economic Growth Corporation. (2017, November 1). DEGC. Retrieved November 10,2017, from http://www.degc.org.

Detroit Historical Society. (n.d.). Encyclopedia of Detroit: Race Riot of 1943. https://detroithistorical.org/learn/encyclopedia-ofdetroit/race-riot-1943

Doucet, B. (2017). Why Detroit matters. Chicago: Policy Press.

Erving, A. M. (2015). Cultural transformations and globalization: Theory, development, and social change. New York, NY: Taylor \& Francis.

Gottesdiener, L. (2013, June 20). Detroit's debt crises: Everything must go. Rolling Stone. Retrieved from https://www.rollingstone.com/politics/politicsnews/detroits-debt-crisis-everything-must-go199255/

Harvey, D. (2005). A brief history of neoliberalism. Oxford: Oxford University Press.

Johnson, M., Nriagu, J., Hammand, A., Savoie, K., \& Jamil, H. (2010). Asthma, environmental risk factors, and hypertension among Arab Americans in metro Detroit. Journal of Immigrant and Minority Health, 12(5), 640-651. https://doi.org/10.1007/s10903-008$9205-8$

Kinney, R. J. (2018). "America's great comeback story": The white possessive in Detroit tourism. American Quarterly, 70(4), 777-806. doi:10.1353/aq.2018.0063

Kinney, R. J. (2017). Detroit is closer than you think. Radical History Review, (129), 164-176. https://doi.org/10.1215/01636545-3920739

Kinney, R. J. (2016). Beautiful wasteland: The rise of Detroit as America's postindustrial frontier. Minneapolis, Minnesota: University of Minnesota Press.

Kurashige, S. (2017). The fifty-year rebellion. How the U.S. political crisis began in Detroit. University of California Press.

Lawless, P. (2002). Power and conflict in pro-growth regimes: Tensions in economic 
development in Jersey City and Detroit. Urban

Studies, 39(8), 1329-1346.

https://doi.org/10.1080/00420980220142664

LeDuff, C. (2013). Detroit: An American autopsy. New York: Penguin Press.

Lipsitz, G. (2007). The racialization of space and the spatialization of race: Theorizing the hidden architecture of landscape. Landscape Journal, 26(1), 10-23.

https://www.jstor.org/stable/43323751

Linder C. (2016). Dora, Apel, Beautiful Terrible Ruins: Detroit and the Anxiety of Decline. Journal of American Studies, 50(3), 1-2. https://doi.org/10.1017/So02187581600075X

Linkon, S. (2013). Narrating past and future: deindustrialized landscapes as resources. International Labor and Working Class History, 84(1), 38-54. https://www.jstor.org/stable/43302726

Lough, A. W. (2016). Hazen S. Pingree and the Detroit model of urban reform. The American Journal of Economics and Sociology, 75(1), 58-85. https://doi.org/10.1111/ajes.12135

Lowe, L. (1996). Immigrant acts: On Asian American cultural politics. Durham, NC: Duke University Press.

Massey, D. (2005). For space. London: Sage Publications.

Marr, S. (2016). Worlding and wilding: Lagos and Detroit as global cities. Race \& Class, 57(4), 3-21. https://doi.org/10.1177/0306396815624863

Martelle, S. (2014). Detroit: A biography. Chicago, Illinois: Chicago Review Press.

Montgomery, A. F. (2015). Different futures for different neighborhoods: The sustainability fix in Detroit. Ethnography, 16(4), 523-555. https://doi.org/10.1177/1466138115570460

Muller, J. (2014). Gilbertville: A billionaire's drive to rebuild The Motor City. Forbes. https://www.forbes.com/sites/joannmuller/2014/og L29/gilbertville-a-billionaires-drive-to-rebuild-themotor-city/?sh=7d4fb34238b3

NAACP. (2016). History of Housing Discrimination Against African Americans in Detroit. NAACP. https://www.naacpldf.org/files/ourwork/Detroit_Housing_Discrimination.pdf

National Park Service. (n.d.) Native American History in Detroit. https://www.nps.gov/articles/ooo/nativeamerican-history-in

detroit.htm\#: : text=Detroit $\% 200$ ccupies $\% 20$ the $\%$ zocontemporary\%20and, by\%2othe\%20city\%2oin $\% 201807$

Pedroni, T. C. (2011). Urban Shrinkage as a performance of whiteness: Neoliberal urban restructuring, education, and racial containment in the postindustrial, global niche city. Discourse: Studies in the Cultural Politics of Education. 32(2), 203-215. https://doi.org/10.1080/01596306.2011.562666

Redmond, S. L. (2013). Detroit's idle: the domestic sounds of labour's foreign landscape. Race \& Class, 55(1), 6o-77. https://doi.org/10.1177/0306396813486595

Robinson, W. I. (2016). Globalization and race in world capitalism. Journal of World- Systems Research, 22(1), 3-8. https://doi.org/10.5195/jwsr.2016.606

Reuther, S. (2012). Brothers on the line. [Motion picture]. Detroit Public TV.

Rothstein, R. (2017). The color of law: A forgotten history of how our government segregated America. New York: Liveright Publishing Corporation.

Safransky, S. (2014). Greening the Urban Frontier: Race, Property, and Resettling in Detroit. Geoforum, 56, 237-248. https://doi.org/10.1016/j.geoforum.2014.06.003

Solomon, L. (2014). Detroit: Three pathways to revitalization. New Brunswick, New Jersey: Transaction Publishers.

Sugrue, T. J. (2014). Motor city: The story of detroit. The Gilder Lehrman Institute of American History. https://www.gilderlehrman.org/history-byera/politics-reform/essays/motor-city-story-detroit

Sugrue, T. J. (1996). The origins of the urban crisis: Race and inequality in postwar Detroit. Princeton, NJ: University Press.

Thompson, H. (1999). Rethinking the politics of white flight in the postwar city. Journal of Urban History, 25(2), 163-198. https://doi.org/10.1177/oog614429902500201 
Trachte, K. C., \& Ross, R. (2003). The crisis of Detroit and the emergence of global capitalism. International Journal of Urban and Regional Research, 9(2), 186217. https://doi.org/10.1111/j.1468-

2427.1985.tboo427.x

Wittenberg, R. (2000). Do unto Others: Toward understanding racial tolerance and acceptance. Journal of College and Character, 1(5), 264-282. https://doi.org/10.2202/1940-1639.1283 